BMJ Surgery, Interventions, \& Health Technologies

\section{Recent progress to shorten premarket evaluation and improve patient access to medical devices by the Pharmaceuticals and Medical Devices Agency of Japan}

\author{
Nobuhiro Handa, ${ }^{\circledR}$ Shinichi Takae, Kensuke Ishii
}

To cite: Handa N, Takae S, Ishii K. Recent progress to shorten premarket evaluation and improve patient access to medical devices by the Pharmaceuticals and Medical Devices Agency of Japan. BMJ Surg Interv Health Technologies 2019;1:e000014. doi:10.1136/ bmjsit-2019-000014

Received 03 June 2019 Accepted 24 June 2019

Check for updates

(C) Author(s) (or their employer(s)) 2019. Re-use permitted under CC BY-NC. No commercial re-use. See rights and permissions. Published by BMJ.

Medical Device Unit, Pharmaceuticals and Medical Devices Agency, Tokyo, Japan

Correspondence to Dr Nobuhiro Handa; handa-nobuhiro@pmda.go.jp
The Pharmaceuticals and Medical Devices Agency (PMDA) of Japan advances the fundamental principle that the safety and effectiveness of all medical products must be reasonably assured before they are approved. However, strict premarket evaluation often delays patients from gaining access to some innovative products. To shorten the premarket evaluation, several initiatives and pieces of legislation, including forerunner designation (the Sakigake fast-track development and review system) ${ }^{1}$ and "Conditional Early Approval System for Innovative Medical Device Products", ${ }^{2}$ have been initiated.

The Sakigake designation provides a concierge (designation of review partner at PMDA), prioritized consultations, presubmission assessments, and prioritized reviews. Currently, nine devices were selected in the last 4 years (table 1 ). The first device was approved. Three requirements to apply for Sakigake designation were described in table 1 as well.

The Conditional Early Approval System is a scheme to approve the innovative new products conditionally for life-threatening disease that do not currently have an effective treatment modality if the effectiveness and the safety are reasonably assured by the existing clinical data analysis. To conduct a new Good Clinical Practice-compliant clinical trial is not requested and the effectiveness and safety continue to be assessed after conditional approval with appropriate risk management plan which includes a creation of proper usage guideline with academic societies and an accumulation of all patient data in the registry. Final approval is granted after data in the registry is evaluated.

The PMDA recognizes that the appropriate method to collect reliable and robust realworld data is often based on the registry that has the potential to facilitate rebalancing between premarket and postmarket conditions. ${ }^{3}$ The registry model is helpful because the development of medical devices is known to follow a total product life cycle that registries can address. ${ }^{4}$ The initiatives of the Clinical Innovation Network led by the Ministry of Health, Labour and Welfare (MHLW) and the PMDA, in collaboration with academia and device manufacturers, facilitate registry development, which is useful for regulatory decision-making. ${ }^{5}$ In addition, the PMDA participated in the International Medical Device Regulators Forum as a Registry Working Group to generate multiple documents related to medical device registry. The utility of the registry includes setting up a control group, technology performance goals in the trial, and safety measures such as post-marketing surveillance and the tracking of patients who have implantable medical devices. The PMDA recognizes that Unique Device Identification system which is under development utilizing GS1 code is essential for patient registry. However, those code has not been linked with the medical database such as adverse event reporting database at PMDA. Linkage with other database such as claims data is a future task to improve the quality of patient registry.

Harmonization by Doing (HBD) activities between the US Food and Drug Administration and the PMDA/MHLW, which were initiated in 2005, have been conducted to promote international clinical trials related to cardiovascular medical devices and obtain approval between countries simultaneously. ${ }^{6}$ HBD activities have also progressed to apply to orphan medical devices for pediatric patients, so-called HBD for children. This special population is important as it remains difficult to conduct 
Table 1 Sakigake assignment for medical devices

\begin{tabular}{|c|c|c|c|c|}
\hline & Date of designation & Name of product & Proposed indication & Sponsor \\
\hline $1 \#$ & 02/10//2016 & $\begin{array}{l}\text { Titanium Bridge } \\
\text { (hinge-type titanium } \\
\text { plates) }\end{array}$ & Adduction-type spasmodic dysphonia & Nobelpharma \\
\hline 2 & 02/28/2017 & $\begin{array}{l}\text { Tracheal prosthesis } \\
\text { (made of polypropylene } \\
\text { mesh and collagen } \\
\text { sponge) }\end{array}$ & $\begin{array}{l}\text { Aiding reconstruction of trachea while } \\
\text { maintaining intratracheal structure after } \\
\text { partial removal }\end{array}$ & Daiichi Medical \\
\hline 3 & 02/28/2017 & $\begin{array}{l}\text { Boron neutron capture } \\
\text { therapy (BNCT) system } \\
\text { (neutron irradiation system } \\
\text { for BNCT) }\end{array}$ & $\begin{array}{l}\text { Glioblastoma, head and neck cancer } \\
\text { (selective destruction of tumor cells marked } \\
\text { by boron agents) }\end{array}$ & $\begin{array}{l}\text { Sumitomo Heavy } \\
\text { Industries }\end{array}$ \\
\hline 4 & $02 / 28 / 2018$ & $\begin{array}{l}\text { UT-Heart } \\
\text { (software to aid cardiac } \\
\text { resynchronization therapy) }\end{array}$ & $\begin{array}{l}\text { Higher accuracy prediction of effectiveness } \\
\text { of cardiac resynchronization therapy for } \\
\text { patients with serious heart failure }\end{array}$ & UT-Heart Corporation \\
\hline 5 & $02 / 28 / 2018$ & $\begin{array}{l}\text { Cardiac repair patch } \\
\text { (combination of } \\
\text { bioabsorbable and } \\
\text { stretchable non- } \\
\text { bioabsorbable synthetic } \\
\text { polymeric threads } \\
\text { and a bridging gelatin } \\
\text { membrane) }\end{array}$ & $\begin{array}{l}\text { A cardiac repair patch used during } \\
\text { cardiovascular interventions } \\
\text { Applied to correct blood flow, maintain } \\
\text { hemoperfusion, and construct/ } \\
\text { reconstruct surrounding tissues }\end{array}$ & Teijin \\
\hline 6 & $02 / 28 / 2018$ & $\begin{array}{l}\text { CliniMACS CD34 System } \\
\text { (CD34 +cell selection and } \\
\text { isolation system) }\end{array}$ & $\begin{array}{l}\text { Product capable of facilitating synostosis } \\
\text { Administered to the site of a non-union } \\
\text { bone fracture with collagen-containing } \\
\text { soft-tissue injection materials as a } \\
\text { scaffold }\end{array}$ & Miltenyi Biotec K.K. \\
\hline 7 & 02/28/2019 & Microwave mammography & $\begin{array}{l}\text { Identifies the tissues suspected of being } \\
\text { breast cancer by microwave and provides } \\
\text { information to the doctor }\end{array}$ & $\begin{array}{l}\text { Integral Geometry } \\
\text { Science Co. }\end{array}$ \\
\hline 8 & 02/28/2019 & $\begin{array}{l}\text { Molds of vascular grafts } \\
\text { for lower extremity arterial } \\
\text { bypass } \\
\text { (in vivo tissue-engineered } \\
\text { vascular grafts) }\end{array}$ & $\begin{array}{l}\text { Improves the blood circulation failure } \\
\text { condition below the knee by surgical } \\
\text { reconstruction, and long-term patency } \\
\text { of self-revascularization for patients with } \\
\text { severe lower-limb ischemia }\end{array}$ & Biotube Co. \\
\hline 9 & $02 / 28 / 2019$ & $\begin{array}{l}\text { Phosphorylated pullulan } \\
\text { bioadhesive }\end{array}$ & $\begin{array}{l}\text { Improves usability and retainability for } \\
\text { bone defects by better formativeness and } \\
\text { adhesiveness by mixing with autologous } \\
\text { bones, allogeneic bones, heterogeneous } \\
\text { bones, artificial bones, or a mixture; } \\
\text { moreover, since it has an increasing effect, } \\
\text { it can reduce the amount of autologous } \\
\text { bone collected }\end{array}$ & BioARC Co. \\
\hline
\end{tabular}

1\#:Titanium Bridge was approved on December 15, 2017.

Three requirements to apply for Sakigake designation were as follows: (1) innovative medical products for serious diseases; (2) development in Japan being world's first or simultaneous with other countries; (3) prominent effectiveness expected on non-clinical and early phase clinical studies.

clinical trials and obtain approval for medical devices for the paediatric patient population.

Through these activities, the PMDA facilitates the development of innovative medical devices and patients' access to them. The PMDA encourages physicians, innovators and manufacturers to utilize these initiatives to obtain approval in the Japanese market.
Contributors NH wrote this manuscript. ST and KI critically revise the manuscript.

Disclaimer The views of this article are personal opinion of the authors and do not necessarily reflect the official one from the PMDA.

Competing interests None declared.

Patient consent for publication Not required.

Provenance and peer review Not commissioned; externally peer reviewed. 
Open access This is an open access article distributed in accordance with the Creative Commons Attribution Non Commercial (CC BY-NC 4.0) license, which permits others to distribute, remix, adapt, build upon this work non-commercially, and license their derivative works on different terms, provided the original work is properly cited, appropriate credit is given, any changes made indicated, and the use is non-commercial. See: http://creativecommons.org/licenses/by-nc/4.0/.

\section{REFERENCES}

1. Strategy of Sakigake. Available: https://www.mhlw.go.jp/english/ policy/health-medical/pharmaceuticals/dl/140729-01-01.pdf [Accessed 30 Jun 2019].
2. Conditional early approval system for innovative medical device products (Fast-Break scheme). Available: http://www.pmda.go.jp/files/ 000227090.pdf\#page $=1$ [Accessed 30 Jun 2019].

3. Balancing Premarket and Postmarket data collection for devices subject to Premarket approval. Available: https://www.fda.gov/media/ 88381/download [Accessed 30 Jun 2019].

4. Sedrakyan A, Campbell B, Merino JG, et al. IDEAL-D: a rational framework for evaluating and regulating the use of medical devices. BMJ 2016;353:i2372.

5. Matsushita S, Tachibana K, Kondoh M. The clinical innovation network: a policy for promoting development of drugs and medical devices in Japan. Drug Discov Today 2019;24:4-8.

6. Japan-US Harmoniztion by doing. Available: http://www.pmda.go.jp/ files/000228372.pdf [Accessed 30 Jun 2019]. 